\title{
VIRAL HEPATITIS C IN A LEADING BRAZILIAN HOSPITAL: EPIDEMIOLOGICAL FACTORS AND GENOTYPING
}

\author{
Cristianne S. Bezerra ${ }^{1}$; José M.C. Lima ${ }^{2}$; Janaina L. Vilar ${ }^{1}$; José L.B. Moreira ${ }^{1}$; Cristiane C. Frota ${ }^{1 *}$ \\ ${ }^{1}$ Divisão de Microbiologia Médica, Departamento de Patologia e Medicina Legal, Universidade Federal do Ceará, Fortaleza, CE, \\ Brasil; ${ }^{2}$ Hospital Universitário Walter Cantidio, Universidade Federal do Ceará, Fortaleza, CE, Brasil
}

Submitted: February 22, 2007; Returned to authors for corrections: May 05, 2007; Approved: September 27, 2007.

\begin{abstract}
The hepatitis $\mathrm{C}$ virus (HCV) is classified into six different genotypes and their distribution is different throughout the world. Epidemiologic studies are important to determine several characteristics of the virus, as well as the disease. This study analysed the prevalence of HCV and its genotypes among patients from a leading hospital in Ceará, which is located in Northeast Brazil. A total of 119 anti-HCV-seropositive patients, each having previously completed a questionnaire about risk behaviours related to $\mathrm{HCV}$ infection were tested for $\mathrm{HCV}$ infection using a qualitative $\mathrm{HCV}$ polymerase chain reaction (PCR) assay and genotyping by restriction fragment length polymorphism (RFLP). The detection was based on amplifying of the non-coding 5' region. Of the 119 patients, 95 showed positive results in the qualitative HCV test. History of surgery was the most reported risk factor, followed by the use of drugs, having tattoos, undergoing haemodialysis and occupational exposure. Genotype 1 was the most prevalent (46.9\%), followed by genotype $3(34.4 \%)$ and $2(8.3 \%)$. The genotype distribution was similar for all of the various risk behaviours.
\end{abstract}

Key words: hepatitis C virus; genotypes; epidemiology; Northeast Brazil; viral hepatitis

\section{INTRODUCTION}

The transmission of the hepatitis $\mathrm{C}$ virus by parenteral exposure is well documented. In the past blood transfusions were the most common channel of HCV transmission. However, the possibility of hepatitis $\mathrm{C}$ infection being transmitted by blood transfusions was reduced (2) after the discovery of HCV (13) and the use of screening tests for hepatitis C (23). Vertical and sexual transmissions may also occur but these are considered to be low risk factors. Injecting-drug users represent the major at-risk group for $\mathrm{HCV}$ transmission; both the incidence and prevalence of $\mathrm{HCV}$ infection remain high. In addition, intranasal cocaine use, being tattooed and body piercing are other modes of HCV transmission $(15,18,21,22,28,32)$.

Genotype determination is important for epidemiological, as well as clinical analysis. HCV genotypes show a distinct geographical distribution. Genotypes 1,2 and 3 are the most frequent in the world, and are found in Japan, Western Europe and North America, while others, such as genotype 4, are found predominantly in Northern and Central Africa, and in the Middle East (27). HCV genotypes are also associated with specific routes of transmission and epidemiological features $(16,35)$.

$\mathrm{HCV}$ genotypes are determined by nucleotide sequencing of the entire genome followed by composing a phylogenetic tree. This is presently the gold standard for detecting and identifying the various HCV genotypes and subtypes (20). Other, more practical genotyping methods are based on serological or molecular techniques. Polymerase chain reaction (PCR) based genotyping methods include the use of genotypespecific primers for amplification, reverse-hybridization analysis using genotype-specific probes for an HCV region and by restriction fragment length polymorphism (RFLP) analysis of the highly conserved 5' non-coding region (NCR) (33).

*Corresponding Author. Mailing address: Divisão de Microbiologia Médica, Departamento de Patologia e Medicina Legal, Faculdade de Medicina, Universidade Federal do Ceará. Rua Monsenhor Furtado, S/N. Rodolfo Teófilo. 60441-750. Fortaleza, CE, Brasil. Tel.: +55 8533668303 . Fax: +55 85 3366-8316. E-mail: ccfrota@ fortalnet.com.br 
A previous study suggested that genotypes 1 and 3 were more prevalent in Brazil (9); however the work was conducted mainly in South and Southeast Regions. Therefore, this study aimed to evaluate the prevalence of HCV genotypes in Ceará (Northeast of Brazil), correlating them with epidemiological data.

\section{MATERIALS AND METHODS}

\section{Patients}

This study was conducted with 119 chronically HCV-infected patients, who were attended at the Walter Cantidio University Hospital, Ceará (Northeast Brazil), between March 2004 and August 2005. The Walter Cantidio University Hospital is considered as the reference hospital in the treatment of $\mathrm{HCV}$ in this state. The study population included $70(58.8 \%)$ men and $49(41.2 \%)$ women, varying from 18 to 80 years old.

The study group included patients with anti-HCV positive blood tests, and also those screened for HCV infection from high-risk groups. These patients came from different parts of the state. A form of consent was obtained from all patients who participated in this study. The Ethical Committee Guidelines of the Medical School, Federal University of Ceará, were followed in the conduct of this research.

\section{HCV RNA detection and genotyping}

HCV-RNA was determined by nested PCR using primers of the $5^{\prime}$ non-coding region of HCV genoma $(11, \underline{12})$ and genotyping by RFLP, as described by Davidson et al. (14) and McOmish et al. (27).

\section{Collection of Epidemiological Data}

Face-to-face interviews were conducted to collect information regarding potential host-related and environmentrelated risk factors to HCV. Extensive medical history was also obtained. Clinical information, including ALT and AST levels, was obtained from the hospital records of each patient and the data used for further analysis. A form of consent was obtained from all patients who participated in this study. The Ethical Committee Guidelines of the Medical School, Federal University of Ceará, were followed in the conduct of this research.

\section{Statistical analysis}

Analysis was performed using two statistical database packages: SPSS version 10 for windows (IL, USA) and Epi-Info 6.04d (CDC, GA, USA). Fisher's exact test and c2 test (Yates corrected) were used to analyse proportions between groups when appropriate. $P$ values $<0.05$ as statistically significant.

\section{RESULTS}

Of the 119 patients, $95(80 \%)$ were found to be positive in the qualitative HCV test. Sixty percent of the positive patients were male. The average age of the patients was 44 , ranging from 18 to 68 years. However, $82 \%$ of the patients $(78 / 95)$ were from 32 to 58 years old (Fig. 1). There was no association between HCV positive PCR and age or gender. Sixty-six percent of the patients had more than seven years of schooling.

None of those studied had anti-bodies for HIV, syphilis, or Chagas. Regarding the HBV infection, results were obtained in 40 cases. Of these, 14 showed some positive HBV markers: three $(7.5 \%) \mathrm{HBsAg}$ positive, two (5\%) anti-HBc IgM positive, ten $(25.0 \%)$ were anti-HBs and anti-HBc IgG positive, and in seven $(17.5 \%)$ the only positive marker was anti-HBs.

The risk of $\mathrm{HCV}$ was found to be associated with a clinical history of surgery. This factor was found in $73.7 \%$ of the HCV positive patients (70/95), with $68.6 \%$ of them having had only one surgical intervention. Caesareans (17.9\%), followed by correction of bone fractures (11.6\%) and colostomies (11.6\%) were the most common procedures reported.

Forty-three patients $(45.3 \%)$ reported having had blood transfusions. Dialyses, tattoos and occupational risk corresponded to $7.3 \%, 10.4 \%$ and $8.3 \%$, respectively, of the HCV positive patients (Table 1). In 1993, an investigation of anti-HCV in the Brazilian blood banks was begun, and in this study it was seen that there was no association between $\mathrm{HCV}$ and blood transfusions before or after $1993(P=0.35$, according to the Fisher test). In contrast, the risk of $\mathrm{HCV}$ increased among drug users; 24 out of 25 patients who were drug users were HCV positive. This pattern was statistically significant $(P=$ 0.04 ; Table 1 ). The patients referred to the use of intravenous or inhaled cocaine and marijuana, and also to the use of an intravenous energy drug (Gluconergan $®$ ).

All of the 95 patients who were positive in the PCR assay were submitted to genotyping (Table 2). It was seen that, genotype 1 was the most prevalent, observed in 45 patients (47.4\%), followed by genotype 3 (33 patients, 34.7\%) and genotype 2 ( 8 patients, $8.4 \%$ ). It was not possible to determine the genotype of nine samples, due to insufficient material.

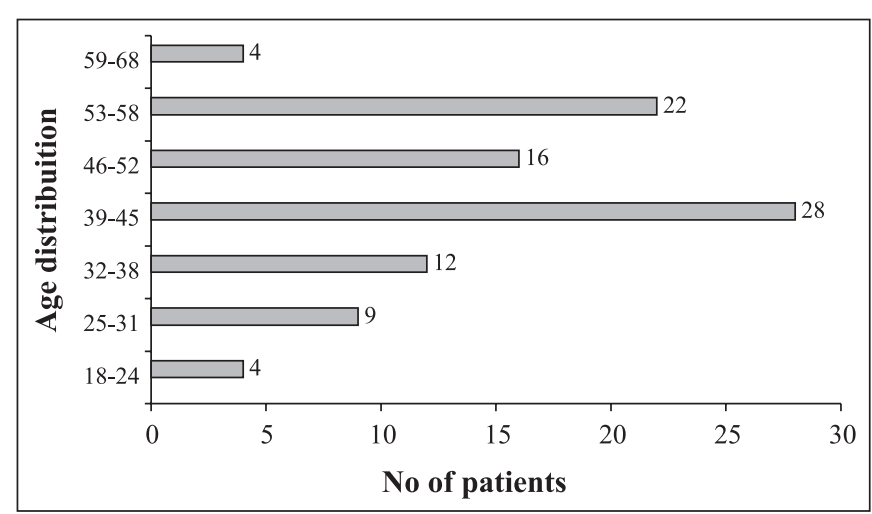

Figure 1. Age distribution of 95 patients with positive qualitative HCV PCR assay. 
The results from the genotype analysis and host-related factors are also presented in Table 2. Genotype 1 was significantly

Table 1. Relation between the risk factors to HCV infection and the result of the qualitative HCV PCR assay.

\begin{tabular}{lccccc}
\hline & \multicolumn{3}{c}{$\begin{array}{c}\text { Result of the qualitative } \\
\text { PCR assay }\end{array}$} \\
\cline { 2 - 5 } Risk factors & Positive & $(\%)$ & Negative & $(\%)$ & $P$ value* \\
\hline Surgery & 70 & $(80)$ & 17 & $(20)$ & NS $\dagger$ \\
Blood transfusion & 44 & $(83)$ & 9 & $(17)$ & NS \\
Use of Drugs & 24 & $(96)$ & 1 & $(4)$ & 0,04 \\
STD's & 30 & $(88)$ & 4 & $(12)$ & NS \\
Tattoos & 10 & $(77)$ & 3 & $(23)$ & NS \\
Dialyses & 7 & $(70)$ & 3 & $(30)$ & NS \\
Occupational risk & 8 & $(80)$ & 2 & $(20)$ & NS \\
\hline
\end{tabular}

* Fisher's exact test; $\dagger$ Not statistically significant. more prevalent among the patients with occupational risk $(P=$ $0.01)$. The investigation revealed that genotypes 1 and 3 were more prevalent in all of the risk factor groups.

\section{DISCUSSION}

This is the first descriptive study to consistently examine $\mathrm{HCV}$ in Ceará, in HIV-negative patients, enabling the respective effects of different factors, as well as HCV, to be investigated. The patients were invited by an experienced physician of a leading medical hospital school in the treatment of hepatitis in Ceará. They were selected based on their clinical history of $\mathrm{HCV}$ or anti-HCV seropositivity.

In this study, the prevalence of $\mathrm{HCV}$ ribonucleic acid (RNA) was higher in male patients and in those who were 39 and over. Similar studies, conducted in other parts of Brazil, found HCV RNA associated with ages of 35 and over $(31,40)$, which could be explained by a combination of age effect and past infection Zarife et al. (40). One person had been infected at the age of 19,

Table 2. Comparison of risk factors and $\mathrm{HCV}$ genotypes in $95 \mathrm{HCV}$ positive patients.

\begin{tabular}{|c|c|c|c|c|c|}
\hline \multirow[b]{2}{*}{ Risk factors $\S$} & \multicolumn{5}{|c|}{ HCV Genotypes } \\
\hline & Type $1(\%)$ & Type $2(\%)$ & Type $3(\%)$ & Indeterminate $(\%)$ & $P$ value* \\
\hline All subjects & $45(47.3)$ & $8(8.4)$ & $33(34.7)$ & $9(9.5)$ & \\
\hline \multicolumn{6}{|l|}{ Surgery } \\
\hline Yes $(n=70)$ & $32(45.7)$ & $5(7.1)$ & $27(38.6)$ & $6(8.6)$ & $\mathrm{NS} \dagger$ \\
\hline No $(n=25)$ & $13(52)$ & $3(12)$ & $6(24)$ & $3(12)$ & NS \\
\hline \multicolumn{6}{|c|}{ Blood transfused } \\
\hline Yes $(n=43)$ & $20(46.5)$ & $5(11.6)$ & $16(37.2)$ & $2(4.7)$ & NS \\
\hline No $(n=52)$ & $25(48)$ & $3(5.8)$ & $17(32.7)$ & $7(13.5)$ & NS \\
\hline \multicolumn{6}{|l|}{ Drug user } \\
\hline Yes $(n=24)$ & $11(45.8)$ & $2(8.4)$ & $8(33.3)$ & $3(12.5)$ & NS \\
\hline No $(n=71)$ & $34(47.8)$ & $6(8.5)$ & $25(35.2)$ & $6(8.5)$ & NS \\
\hline \multicolumn{6}{|l|}{ STD } \\
\hline Yes $(n=29)$ & $13(44.8)$ & $4(13.8)$ & $10(34.5)$ & $2(6.9)$ & NS \\
\hline No $(n=66)$ & $32(48.5)$ & $4(6.1)$ & $23(34.8)$ & $7(10.6)$ & NS \\
\hline \multicolumn{6}{|l|}{ Any tattoos } \\
\hline Yes $(n=10)$ & $6(60)$ & $0(0)$ & $4(40)$ & $0(0)$ & NS \\
\hline No $(n=85)$ & $39(45.9)$ & $8(9.4)$ & $29(34.1)$ & $9(10.6)$ & NS \\
\hline \multicolumn{6}{|l|}{ Dialyses } \\
\hline Yes $(n=7)$ & $4(57.1)$ & $0(0)$ & $3(42.9)$ & $0(0)$ & NS \\
\hline No $(n=88)$ & $41(46.6)$ & $8(9.1)$ & $30(34.1)$ & $9(10.2)$ & NS \\
\hline \multicolumn{6}{|c|}{ Occupational exposure } \\
\hline Yes $(n=8)$ & $7(87.5)$ & $0(0)$ & $1(12.5)$ & $0(0)$ & $0.01 *$ \\
\hline No $(n=87)$ & $38(43.7)$ & $8(9.2)$ & $32(36.8)$ & $9(10.3)$ & NS \\
\hline
\end{tabular}

$\S$ Totals vary according to the availability of data; * Fisher's exact test; $\uparrow$ Not statistically significant. 
while all the others were 30 or older. Zarife's findings were similar to this study's data which found four patients under 25. Similarly, two independent studies conducted in the United States and Italy; also demonstrate that $\mathrm{HCV}$ positive patients were between 40 and 60 years $(3,39)$. The association of $\mathrm{HCV}$ with gender is still not clear, since the results of several studies are quite different. Zarife et al. (40) found a higher prevalence in women, whereas Silva et al. (36) and Bassit et al. (4) found predominance in men. However, Albuquerque et al. (1) and Busek et al. (9) did not find any significant correlation between gender and HCV. Other studies conducted in Australia (2204) and Italy (19) showed that $\mathrm{HCV}$ was more prevalent in the female population, while in Poland (7), more in males. The link between HCV and males may reflect the differences related to stigma and its social consequences thus resulting in differences in health-seeking behaviour.

In the PCR assay, HCV RNA was found in $80.3 \%$ of the samples which were positive by ELISA (49/61). Six of these were positive by the immunoblot assay, nine were undetermined and one was negative by the immunoblot assay. The negative results in the immunoblot assay might reflect the beginning of an infection or an immunocompromised effect. Although there have been improvements in the new version of the ELISA assay, the proportion of positivity confirmation is about $80 \%$ among low-risk populations (38). Patients may also develop a chronic infection, showing a positive immunoblot assay or being undetermined, while not showing HCV RNA.

Before the introduction of anti-HCV screening, several other publications described that blood transfusions were significantly associated with $\mathrm{HCV}$ infection $(1,5,6)$. In this work, the history of blood transfusions was the most prevalent of all risk factors which were studied. Of the patients having had transfusions, 44 of 53 were positive in the qualitative HCV test. Nevertheless, the high prevalence of patients having had blood transfusions compared to the other risk factors may be a consequence of a campaign conducted in 2004 by the Federal Health Ministry advising the population who had received blood transfusions before 1993 to be anti-HCV screened. However, there was no statistical significance in the number of patients who had received blood transfusions before 1993 compared to those after that date.

$\mathrm{HCV}$ was more prevalent among drug users than in other exposure behaviors. This was similar to that described by Shepard et al. (34), who reported $64 \%$ to $94 \%$ worldwide with the prevalence being directly related to the duration of the exposure. The participants were not asked to state when they first used drugs, how often they used them or if they had shared recipient syringes. However, a group of former footballers reported having shared or reused recipient syringes to inject an energy drug (Gluconergan $\left.{ }^{\circledR}\right)$. In São Paulo, Silva et al. (36) showed a prevalence of $41 \%$ among blood donors for this risk factor. Oliveira et al. (29) and Smyth et al. (37) showed an odds ratio for infection of $\sim 3$ for each 10 -fold increase in the number of lifetime injecting episodes for those who shared needles/syringes compared to those who injected with sterile ones.

The patients in this study stated that they had only used inhaled drugs, however based on Dunn and Laranjeira (17) who reported that $74 \%$ of cocaine users underwent at least one transition in the way the drug was administered. The idea that there was intravenous drug use cannot be discarded. Nowadays, the use of intravenous drugs, particularly cocaine, is the major channel for the transmission of hepatitis $\mathrm{C}(16,34)$.

The results of this study showed HCV infection was also associated to Sexual Transmitted Disease (STD), which indicated at-risk sexual behaviour. However most of the patients were exposed to at least one other associated risk condition. A Siberian study reported that the risk factor for HCV infection was higher among patients who had at least four sexual partners during their lives history, homosexual behaviour, or a history of STD (35). All other potential risk factors reported by the patients (HCV RNA-positive heterosexual partner, two or more heterosexual partners, dental procedures, body piercing and tattooing) also appeared in a study carried out by Brojer $e t$ al. (7) and Orton et al. (30). The results confirm the advantage of interviewing rather than patients completing a routine questionnaire to identify risk factors.

Regarding occupational exposure, the prevalence of $\mathrm{HCV}$ patients among professionals who work in hospitals or clinical laboratories was similar to the findings described by Shustov and co-workers (35). There was no significant impact on HCV positivity.

Most patients had history of surgery; nevertheless, they were also exposed to other elements of risk. Recent studies have described low or no association to HCV for patients who had previously undergone surgery, general anaesthetic or dental treatment $(24,35)$. On the other hand, an African study showed a rate of $50 \%$ of $\mathrm{HCV}$ positivity among patients who were given injections without proper safety measures or with non-sterile needles and syringes, therefore contributing to the $\mathrm{HCV}$ dissemination in that continent (25).

In this article, the results of distribution of HCV genotypes and epidemiologic analysis on the infection sources are presented. In Ceará, the proportion of genotypes 1, 2 and 3 were $47.3 \%, 8.4 \%$ e $34.7 \%$, respectively. The genotype of the other nine samples could not be determined due to insufficient material. These data were similar to those previously found in Brazil, where genotype 1 is predominant $(1,4,26,31,36)$. These data are in contrast to the genotype distribution observed by Busek et al. (8) in a study conducted among ten patients from a haemodialysis centre, where there was a higher prevalence of genotype 3 followed by genotypes 1 and 2. More recently, a study conducted by Campiotto et al. (10) with 23 patients showed the following genotype distribution in Northeast 
Region: genotype 1 was the most common (66.4\%), followed by genotype $3(30.4 \%)$ and genotype $2(3.0 \%)$. Although genotype 1 was significantly associated with health care workers, the risk factors were not linked to any particular genotype. Analysing the associations of HCV types 1, 2 and 3 to gender, age, risk factors, severity of the hepatic lesion, other diseases and educational level, no significant correlations were found.

These data reinforce the need for patient follow-up and the use of nucleic acid sequencing techniques in order to explain the HCV epidemiology in Brazil, as well as investigate the genotypes which could not be determined. In order to better explain HCV epidemiology, there should be more studies targeting specific groups, like injecting drug users or patients under-going haemodialysis.

\section{ACKNOWLEDGMENTS}

We thank the patients who participated in the study and hospital staff at Walter Cantidio University Hospital. We acknowledge the Health Secretary of Sobral and Fortaleza, also CAPES/Brazil for funding the study.

\section{RESUMO}

\section{Hepatite pelo Vírus C em hospital de referência brasileiro: fatores epidemiológicos e genotipagem}

$\mathrm{O}$ vírus da hepatite $\mathrm{C}(\mathrm{VHC})$ é classificado em seis genótipos diferentes e sua distribuição é diferente em todo o mundo. Os estudos epidemiológicos são importantes para determinar várias características sobre o vírus, bem como da doença. Este estudo analisou a prevalência do VHC e seus genótipos em pacientes atendidos em hospital de referência no Ceará, o qual é localizado no nordeste do Brasil. Um total de 119 pacientes, os quais eram soropositivos anti-VHC, preencheram questionários sobre fatores de risco relacionados à infecção pelo VHC e foram testados quanto à infecção ao VHC usando o teste da reação da polimerase em cadeia (PCR) qualitativo para VHC e genotipagem por "restriction fragment length polymorphism" (RFLP). A detecção foi baseada na amplificação da região não codificante $5^{\prime}$. Dos 119 pacientes, 95 mostraram resultados positivos no teste qualitativo para VHC. A história prévia de cirurgia foi o fator de risco mais relatado, seguido pelo uso de drogas, ter tatuagem, ter sido submetido à hemodiálise e risco ocupacional. O genótipo 1 foi o mais prevalente $(46,9 \%)$, seguido pelo genótipo $3(34,4 \%)$ e $2(8,3 \%)$. A distribuição dos genótipos foi similar entre os vários fatores de risco analisados.

Palavras-chave: virus da hepatite $\mathrm{C}$, genótipos, epidemiologia, nordestes do Brasil, hepatite pelo vírus $\mathrm{C}$

\section{REFERENCES}

1. Albuquerque, A.C.; Coelho, M.R.; Lopes, E.P.; Lemos, M.F.; Moreira, R.C. (2005). Prevalence and risk factors of hepatitis C virus infection in hemodialysis patients from one center in Recife, Brazil. Mem. Inst. Oswaldo Cruz., 100(5), 467-470.

2. Allain, J.P. (2003). Transfusion risks of yesterday and of today. Transfus. Clin. Biol., 10(1), 1-5.

3. Ansaldi, F.; Bruzzone, B.; Salmaso, S.; Rota, M.C.; Durando, P.; Gasparini, R.; Icardi, G. (2005). Different seroprevalence and molecular epidemiology patterns of hepatitis $\mathrm{C}$ virus infection in Italy. J. Med. Virol., 76(3), 327-332.

4. Bassit, L.; Da Silva, L.C.; Ribeiro-dos-Santos, G.; Maertens, G.; Carrilho, F.J.; Fonseca, L.E.; Alves, V.A.; Gayotto, L.C.; Pereira, A.N.; Takei, K.; Chamone, D.; Saez-Alquezar, A. (1999). Chronic hepatitis $\mathrm{C}$ virus infections in brazilian patients: association with genotypes, clinical parameters and response to long term alpha interferon therapy. Rev. Inst. Med. Trop. Sao Paulo, 41(3), 183189.

5. Bdour, S. (2002). Hepatitis C virus infection in Jordanian haemodialysis units: serological diagnosis and genotyping. J. Med. Microbiol., 51(8), 700-704.

6. Bellentani, S.; Miglioli, L.; Masutti, F.; Saccoccio, G.; Tiribelli, C. (2000). Epidemiology of hepatitis C virus infection in Italy: the slowly unraveling mystery. Microbes. Infect., 2(14), 1757-1763.

7. Brojer, E.; Gronowska, A.; Medynska, J.; Grabarczyk, P.; Mikulska, M.; Letowska, M.; Kryczka, W.; Gietka, A. (2004). The hepatitis C virus genotype and subtype frequency in hepatitis $\mathrm{C}$ virus RNApositive, hepatitis $\mathrm{C}$ virus antibody-negative blood donors identified in the nucleic acid test screening program. Poland. Transfusion., 44(12), 1706-1710.

8. Busek, S.; Oliveira, G. (2003). Molecular epidemiology of the hepatitis C virus in Brazil. Genet. Mol. Res., 2(1), 117-123.

9. Busek, S.U.; Baba, E.H.; Tavares Filho, H.A.; Pimenta, L.; Salomao, A.; Correa-Oliveira, R.; Oliveira, G.C. (2002). Hepatitis C and hepatitis B virus infection in different hemodialysis units in Belo Horizonte, Minas Gerais, Brazil. Mem. Inst. Oswaldo Cruz, 97(6), 775-778.

10. Campiotto, S.; Pinho, J.R.; Carrilho, F.J.; Da Silva, L.C.; Souto, F.J.; Spinelli, V.; Pereira, L.M.; Coelho, H.S.; Silva, A.O.; Fonseca, J.C.; Rosa, H.; Lacet, C.M.; Bernardini, A.P. (2005). Geographic distribution of hepatitis $\mathrm{C}$ virus genotypes in Brazil. Braz. J. Med. Biol. Res., 38(1), 41-49.

11. Chan, S.W.; Mcomish, F.; Holmes, E.C.; Dow, B.; Peutherer, J.F.; Follett, E.; Yap, P.L.; Simmonds, P. (1992). Analysis of a new hepatitis $\mathrm{C}$ virus type and its phylogenetic relationship to existing variants. J. Gen. Virol., 73(Pt 5), 1131-1141.

12. Chomczynski, P.; Sacchi, N. (1987). Single-step method of RNA isolation by acid guanidinium thiocyanate-phenol-chloroform extraction. Anal. Biochem., 162(1), 156-159.

13. Choo, Q.L.; Kuo, G.; Weiner, A.J.; Overby, L.R.; Bradley, D.W.; Houghton, M. (1989). Isolation of a cDNA clone derived from a blood-borne non-A, non-B viral hepatitis genome. Science, 244 (4902), 359-362.

14. Davidson, F.; Simmonds, P.; Ferguson, J.C.; Jarvis, L.M.; Dow, B.C.; Follett, E.A.; Seed, C.R.; Krusius, T.; Lin, C.; Medgyesi, G.A. et al. (1995). Survey of major genotypes and subtypes of hepatitis C virus using RFLP of sequences amplified from the 5 ' non-coding region. $J$. Gen. Virol., 76(Pt 5), 1197-1204.

15. Dev, A.; Sundararajan, V.; Sievert, W. (2004). Ethnic and cultural determinants influence risk assessment for hepatitis $\mathrm{C}$ acquisition. $J$. Gastroenterol. Hepatol., 19(7), 792-798.

16. Dore, G.J.; MacDonald, M.; Law, M.G.; Kaldor, J.M. (2003). Epidemiology of hepatitis C virus infection in Australia. Aust. Fam. Physician., 32(10), 796-798. 
17. Dunn, J.; Laranjeira, R.R. (1999). Transitions in the route of cocaine administration-characteristics, direction and associated variables. Addiction., 94(6), 813-824.

18. Ghosn, J.; Leruez-Ville, M.; Chaix, M.L. (2005). Sexual transmission of hepatitis C virus. Presse. Med., 34(14), 1034-1038.

19. Guadagnino, V.; Stroffolini, T.; Rapicetta, M.; Costantino, A.; Kondili, L.A.; Menniti-Ippolito, F.; Caroleo, B.; Costa, C.; Griffo, G.; Loiacono, L.; Pisani, V.; Foca, A.; Piazza, M. (1997). Prevalence, risk factors, and genotype distribution of hepatitis $\mathrm{C}$ virus infection in the general population: a community-based survey in southern Italy. Hepatology, 26(4), 1006-1011.

20. Haushofer, A.C.; Berg, J.; Hauer, R.; Trubert-Exinger, D.; Stekel, H.G.; Kessler, H.H. (2003). Genotyping of hepatitis C viruscomparison of three assays. J. Clin. Virol., 27(3), 276-285.

21. Hellard, M.; Aitken, C.; Mackintosh, A.; Ridge, A.; Bowden, S. (2003). Investigation of infection control practices and knowledge of hepatitis $\mathrm{C}$ among body-piercing practitioners. Am. J. Infect. Control., 31(4), 215-220.

22. Hellard, M.E.; Hocking, J.S.; Crofts, N. (2004). The prevalence and the risk behaviours associated with the transmission of hepatitis $\mathrm{C}$ virus in Australian correctional facilities. Epidemiol. Infect., 132(3), 409-415.

23. Kuo, G.; Choo, Q.L.; Alter, H.J.; Gitnick, G.L.; Redeker, A.G.; Purcell, R.H.; Miyamura, T.; Dienstag, J.L.; Alter, M.J.; Stevens, C.E. et al. (1989). An assay for circulating antibodies to a major etiologic virus of human non-A, non-B hepatitis. Science, 244(4902), 362-364.

24. Leao, J.C.; Teo, C.G.; Porter, S.R. (2006). HCV infection: aspects of epidemiology and transmission relevant to oral health care workers. Int. J. Oral. Maxillofac. Surg., 35(4), 295-300.

25. Madhava, V.; Burgess, C.; Drucker, E. (2002). Epidemiology of chronic hepatitis $\mathrm{C}$ virus infection in sub-Saharan Africa. Lancet. Infect. Dis., 2(5), 293-302.

26. Martins, R.M.; Teles, S.A.; Freitas, N.R.; Motta-Castro, A.R.; Souto, F.J.; Mussi, A.; Amorim, R.M.; Martins, C.R. (2006). Distribution of hepatitis $\mathrm{C}$ virus genotypes among blood donors from mid-west region of Brazil. Rev. Inst. Med. Trop. São Paulo, 48(1), 53-55.

27. McOmish, F.; Yap, P.L.; Dow, B.C.; Follett, E.A.; Seed, C.; Keller, A.J.; Cobain, T.J.; Krusius, T.; Kolho, E.; Naukkarinen, R.; et al. (1994). Geographical distribution of hepatitis C virus genotypes in blood donors: an international collaborative survey. J. Clin. Microbiol., 32(4), 884-892.

28. Nishioka, S.A.; Gyorkos, T.W. (2001). Tattoos as risk factors for transfusion-transmitted diseases. Int. J. Infect. Dis., 5(1), 27-34.
29. Oliveira, Mde.L.; Hacker, M.A.; Oliveira, S.A.; Telles, P.R.; O, K.M.; Yoshida, C.F.; Bastos, F.I. (2006). "The first shot": the context of first injection of illicit drugs, ongoing injecting practices, and hepatitis C infection in Rio de Janeiro, Brazil. Cad. Saude. Publica, 22(4), 861-870.

30. Orton, S.L.; Stramer, S.L.; Dodd, R.Y.; Alter, M.J. (2004). Risk factors for $\mathrm{HCV}$ infection among blood donors confirmed to be positive for the presence of HCV RNA and not reactive for the presence of anti-HCV. Transfusion., 44(2), 275-281.

31. Parana, R.; Vitvitski, L.; Berby, F.; Portugal, M.; Cotrim, H.P.; Cavalcante, A.; Lyra, L.; Trepo, C. (2000). HCV infection in northeastern Brazil: unexpected high prevalence of genotype $3 \mathrm{a}$ and absence of African genotypes. Arq. Gastroenterol., 37(4), 213-216.

32. Paternoster, D.M.; Santarossa, C.; Grella, P.; Palu, G.; Baldo, V.; Boccagni, P.; Floreani, A. (2001). Viral load in HCV RNA-positive pregnant women. Am. J. Gastroenterol., 96(9), 2751-2754.

33. Pawlotsky, J.M. (1999). Diagnostic tests for hepatitis C. J. Hepatol. 31(Suppl 1), 71-79.

34. Shepard, C.W.; Finelli, L.; Alter, M.J. (2005). Global epidemiology of hepatitis C virus infection. Lancet. Infect. Dis., 5(9), 558-567.

35. Shustov, A.V.; Kochneva, G.V.; Sivolobova, G.F.; Grazhdantseva, A.A.; Gavrilova, I.V.; Akinfeeva, L.A.; Rakova, I.G.; Aleshina, M.V.; Bukin, V.N.; Orlovsky, V.G.; Bespalov, V.S.; Robertson, B.H.; Netesov, S.V (2005). Molecular epidemiology of the hepatitis C virus in Western Siberia. J. Med. Virol., 77(3), 382-389.

36. Silva, G.F.; Nishimura, N.F.; Coelho, K.I.; Soares, E.C. (2005). Grading and staging chronic hepatitis $\mathrm{C}$ and its relation to genotypes and epidemiological factors in Brazilian blood donors. Braz. J. Infect. Dis., 9(2), 142-149.

37. Smyth, B.P.; Barry, J.; Keenan, E. (2005). Irish injecting drug users and hepatitis $C$ : the importance of the social context of injecting. Int. J. Epidemiol., 34(1), 166-172.

38. Tobler, L.H.; Lee, S.R.; Stramer, S.L.; Peterson, J.; Kochesky, R. Watanabe, K.; Quan, S.; Polito, A.; Busch, M.P. (2000). Performance of second- and third-generation RIBAs for confirmation of thirdgeneration HCV EIA-reactive blood donations. Retrovirus Epidemiology Donor Study. Transfusion., 40(8), 917-923.

39. Williams, I. (1999). Epidemiology of hepatitis C in the United States. Am. J. Med., 107(6 B), 2S-9S.

40. Zarife, M.A.; Silva, L.K.; Silva, M.B.; Lopes, G.B.; Barreto, M.L.; Teixeira, Mda.G.; Dourado, I.; Reis, M.G. (2006). Prevalence of hepatitis $\mathrm{C}$ virus infection in north-eastern Brazil: a populationbased study. Trans. R. Soc. Trop. Med. Hyg., 100(7), 663-668. 